\title{
Re-Visits the Grand Theory of Geoffrey Leech: Seven Types of Meaning
}

\author{
Sandra Yunira ${ }^{1}$, Siska Pradina ${ }^{2}$, Mathilda Sumbayak ${ }^{3}$, Nunung Susilo Putri ${ }^{4}$ and Tatum Derin ${ }^{5}$ \\ ${ }^{1}$ SMK Negeri 5 Pekanbaru. Indonesia \\ 2, 3, 4, 5 U-Raise Academy, Pekanbaru, Indonesia \\ sandrayunira98@gmail.com
}

\author{
Received : 2019-12-02 \\ Revised : 2019-12-06 \\ Accepted : 2019-12-29

\section{KEYWORDS} \\ Geoffrey Leech \\ Semantics \\ Meaning \\ Qualitative Approach \\ Linguistics
}

ARTICLE HISTORY

\begin{abstract}
Meaning is the field of the study discussed in the semantic field. Semantics is a branch of linguistics that studies the meaning of words in languages. This present study would like to set thought and argues that the meaning of a word in language can be known with the foundation of semantic perspective. Therefore, this present study focused on explaining its thought based on the seven types of meaning and their descriptions in the book of Semantics by Geoffrey Leech: 1981. The research aims to classify and to identify seven types of meanings, and also to analyze Leech's book and three article reviews of his theory. This present study uses a qualitative approach focusing on the words, phrases, and sentences regarding the theory. The result of this research believes that there are seven types of meaning just as Leech's mentioned in his theory, namely conceptual, connotative, collocative, reflective, affective, social, and thematic. This present study also found that the seven types of meaning have variations in their descriptions which somehow liked to connotative meaning, social meaning, affective meaning, reflected meaning and collocative meaning include to associative meaning.
\end{abstract}

\section{Introduction}

This present study tries to make a point by revisiting the theory proposed by Geoffrey Leech 1981, which explain and divided meaning into seven types. These seven types of meaning, for so long being supported and used by many studies, however at the same time it is also contradict or argue by many scholars across the discipline. Therefore, this study tries to revisit the theory from several studies which support the theory in order to see their perspectives and enriching our knowledge regarding meaning.

Moreover, it is important to understand that to be understood by people, it is supposed to by meaningful communication; words must have a meaning. This exactly where semantic comes in, to help anyone understand words. It's been a general knowledge have more than one meaning. In reality, the word is very helpful in our life due to its variety of meaning. Word is related to the situation of human; it's not used in isolation.

According to Crystal (1991: 310), that "Semantics is one of the branches of linguistics that studies about meaning, and is considered to be the main branch in linguistics that aims to study a meaning in language). Researchers traditionally defined semantics as the study of meaning, and this is the definition we will initially adopt. Crystal (1991: 100) also says that "the study of the Meaning traits is an important part of semantics, but it is only partial. Even more important is the study of the way words and sentences convey meaning in everyday situations of speaking and writing. (Lyons (1997: 1) stated that semantics is a study that discusses meaning. Semantics also has significant ties to various theories of representative meaning, including the theory of truth of meaning, the theory of coherence of meaning, and the theory of correspondence of meaning."

The term semantics is widely used to refer to the study of meaning. It is also important for communication studies. However, the 'meaning' or information to be communicated can be conveyed in several ways, such as movements, images, signals, etc. Language is the main tool of human communication. Semantics, as a branch of linguistics, mainly deals with how 'meaning' is conveyed by the linguistic system which consists of different unit structures such as sentences, phrases, words, morphemes, etc. Semantics, as the study of meaning, which connects language with various aspects of non-linguistic reality, also appeals to various disciplines such as philosophy, anthropology, psychology, communication theory etc., Semantics in the broadest sense of the term can be considered to study all that communicates with language. Still, some scholars would like to limit semantics to the study of logical or conceptual meaning only those aspects of meaning that are logically acceptable, leaving deviations and deviations. 
The meaning of the word is a field of the study discussed in semantic science. Semantics is a branch of linguistics that studies the meaning of words in languages. Linguistics, by contrast, is the study of spoken and written languages that have systematic, rational, empirical characteristics as a description of the structure and rules of language (Nurhayati, 2009:3). Based on the above opinion, it can be concluded that the meaning of a word in language can be known with the foundation of semantic science. Hornby (in Pateda, 1989: 45) argues that meaning is what we mean or what we mean. Poerwadarminta (in Pateda, 1989: 45) says meaning: meaning or purpose. The Big Indonesian Dictionary (in Pateda, 2001: 82) the word meaning means: (i) meaning: it pays attention to the meaning of each word contained in the ancient writing, (ii) the meaning of the speaker or writer, (iii) the meaning given to a form language. The meaning is the relationship between language and the outside world that has been mutually agreed upon by the users of language so that it can be understood by one another (Aminuddin, 1988: 53).

From the limits of that understanding, it can be seen that there are three main elements included in it. First, the meaning is the result of the relationship between language and the outside world. Second, relationship determination occurs because of the agreement of the users. Third, authorization and meaning can be used to convey information so that they can be mutually understood. According to (Leech, 1981) "Semantics is the study of meaning in language. We know that language is used to express meanings that can be understood by others. But the meaning is in our minds, and we can express what is in our minds through forms of spoken and written language (also through movements, actions, etc.)" Sound patterns of language are learned at the phonological level, and the organization of words and sentences is studied at the morphological and syntactic levels. These, in turn, are arranged so that we can convey meaningful messages or receive and understand messages. "How is language organized to be meaningful?" These are the questions we ask and try to answer at the semantic level. Semantics is the level of linguistic analysis in which meaning is analyzed. This is the most abstract level of linguistic analysis because we cannot see or observe meaning as we can observe and record sound. The meaning is closely related to the human capacity to think logically and understand. Therefore, when we try to analyze meaning, we try to analyze our own ability to think and understand our own ability to create meaning. Semantics focuses on "providing a systematic explanation of the nature of meaning".

Geoffrey Leech, in his semantic book, breaks down "meaning" in a broad sense into seven different types which give primary importance to logical or conceptual meanings.
According to Geoffrey Leech (1981: 8), meaning can be learned as a linguistic phenomenon itself, not as something outside of language. However, the scope of linguistics that studies about meaning does not only consist of one field of science.

According to Leech, there are only seven types of meaning. Meaning plays an important role in understanding what is communicated. As such, there are seven types of meaning, and they contribute a lot to the semantic field. The study of meaning is a new field of this century, in the future; This field of study will advance and will have a lot of value in the analysis of meaning in the field of linguistics.

In general, it is classified into seven types of meaning in which five of them are identified as associative meanings. Seven types of meanings are conceptual meanings, thematic meanings, and associative meanings; connotative meaning, style meaning, affective meaning, reflected meaning, and collocative meaning. The definition of associative meaning is unstable in meaning and has individual experience variants (Leech, 1974: 21). The associative meaning of expressions is related to the mental understanding of the individual speaker. They can be broken down into five subtypes, e.g. connotative, style, affective, reflected, and collocative meaning.

\section{Methodology}

This present study uses a qualitative approach focusing on the words, phrases, and sentences regarding the theory of Geoffrey Leech. This study presents to Re-visits the theory of Leech about seven types of meaning on his book 'Semantic', and also the writer uses the reference by three article reviews of Geoffrey Leech.

\section{Results \& Discussion}

The result of this research confirmed that there are seven types of meaning based on Leech's theory, namely: conceptual meaning, connotative meaning, collocative meaning, reflective meaning, affective meaning, social meaning, and thematic meaning. The new of this present study found is that the seven types of meaning have variations in their descriptions.

\subsection{Conceptual Meaning}

What Leech calls conceptual meaning is the same as what other scholars call 'denotative', or 'designative', or 'cognitive', or 'descriptive' meaning. And this meaning is considered a central factor in linguistic communication. It is an integral part of the essential function of a language while other types of meaning do not. Leeches regard conceptual meaning as primary because it is comparable in organization and structure to the syntactical and phonological level of language. 
Two structural principles that seem to be the basis of all linguistic patterns, namely the principle of counteractivity and the principle of the structure are also the basis of conceptual meaning. The second principle, namely structure, is the principle by which larger linguistic units are built from smaller units. In other words, it is the principles by which sentences can be analyzed into parts. Here also when sentences are analyzed into their units, namely words and morphemes, and at the phonological level into phonemes (sound units), the same semantic sentence structure can also be explained.

The two constituent structural principles represent the way language is organized. Contractility is a paradigmatic aspect or selection or 'choice' of linguistic structure. The constituent structure is a syntagmatic or combinatoric aspect of linguistic structure 'chain'. Explaining these two aspects at all levels of language organization is called phonological (sound structure), syntax (sentence structure) semantics (meaning) is the work of linguists. This is done by specifying, 'phonological representation', 'syntactic representation' and 'semantic representation' and the stage at which one level of representation can be derived from another.

At the level of semantic representation, the conceptual meaning of a sentence will be explained in the form of semantic representation using abstract symbols and contrast features. This will help people to know to distinguish the meaning of certain sentences from all other possible sentences in the language. This representation will also match the meaning of the sentence with the appropriate syntactic and phonological forms.

Conceptual meaning refers to the logical understanding of speech and is recognized as a basic component of grammatical competence. The alternative is described as cognitive or denotative meaning (denotation) (see Lyons 1981). This is a basic or universal meaning and can be represented at the lexical level, as well as the meaning of simple clauses or sentences. At the lexical level (lexeme), the conceptual meaning is represented as a series of different features.

The set of relevant special features, if not described as semes or semema, depends on the given semantic field. The operand features for lexeme 'people are [human], [adult], [male]. The application of these features uses binary notation where the value of the feature is determined as one positive [+], negative [-] or neutral [₹]. Consider the meaning of Kiswahili: mtu 'person', mtoto 'child', mzee 'parent', kijana 'youth', mwanamke 'woman', mwanamume 'man', mulana 'boy', msichana 'girl'.

\begin{tabular}{|c|c|c|c|}
\hline mtu & $\rightarrow$ & $\begin{array}{l}\text { [+ human }],[\bar{\mp} \text { adult }], \\
{[\bar{\mp} \text { male }]}\end{array}$ & mtu \\
\hline mtoto & $\rightarrow$ & $\begin{array}{l}\text { [+ human }],[- \text { adult }], \\
{[\mp \text { male }]}\end{array}$ & mtoto \\
\hline mzee & $\rightarrow$ & $\begin{array}{l}\text { [+human }],[+ \text { adult }], \\
{[\mp \text { male }]}\end{array}$ & mzee \\
\hline kijana & $\rightarrow$ & $\begin{array}{l}{[+ \text { human }],[\mp \text { adult }],} \\
{[\mp \text { male }]}\end{array}$ & kijana \\
\hline mke & $\rightarrow$ & $\begin{array}{l}{[+ \text { human }],[+ \text { adult }],} \\
{[- \text { male }]}\end{array}$ & mke \\
\hline mume & $\rightarrow$ & $\begin{array}{l}{[+ \text { human }],[+ \text { adult }],} \\
{[+ \text { male }]}\end{array}$ & mume \\
\hline mvulana & $\rightarrow$ & $\begin{array}{l}\text { [+ human }],[- \text { adult }] \\
{[+ \text { male }]}\end{array}$ & mvulana \\
\hline msichana & $\rightarrow$ & $\begin{array}{l}{[+ \text { human }],[- \text { adult }]} \\
{[- \text { male }]}\end{array}$ & msichana \\
\hline
\end{tabular}

In addition to distinguishing meanings, semantic features serve as a basis for comparing and differentiating lexemes. All these lexemes share [+ human] features. Otherwise, the lexeme pair compares or contrasts based on other properties as illustrated in the semantic rules represented above. The conceptual structure of a simple clause or sentence will be represented as a set of meaningful postulates. Operant postulates refer to certain basic assumptions of the lexeme and are represented as semantic rules. Consider the two Kiswahili expressions that are appropriate.

$\begin{aligned} & \text { Karama (X) ni mwanamume. 'Karama is a man.' } \\ & \text { Selina (Y) ni mwanamke. } \\ & \mathrm{X} \rightarrow \quad \text { a person } \\ & \text { an adult } \\ & \text { possessing the biological properties of a male }\end{aligned}$
$\mathrm{Y} \rightarrow$ a person
an adult
possessing the biological properties of a female

\subsection{Connotative Meaning}

For the sake of defining precisely this type of meaning, Leech's book on semantics needs to be consulted once again: "Connotative meaning is the communicative value of expression based on what it refers to, exceeds and above its pure conceptual content." (Leech 1981, 12) As can be seen from the definition, connotative meanings inevitably overlap with certain aspects of conceptual meanings.

Therefore, "reference" overlaps with elements of conceptual meaning, such as when the contrasting features of conceptual meaning become attributes of "real-world" references. But the additional attributes 
expected from the reference depend on various other factors, such as age or society, and they can also depend on the individual, as claimed by Leech (1981: 12).

In this context, the relationship between conceptual and connotative meaning can be easily compared to the relationship between language (conceptual) and "real world" (connotative). For this reason, connotative meanings can be seen as open and unstable categories compared to conceptual meanings. (Leech 1981: 12).

Leech said that connotative meaning is the communicative value possessed by an expression based on what if it refers to and above its pure conceptual content. This is a feature of a reference, denotatum or segment of the real world which is not included in the conceptual meaning. From various features of several references, there are constructive features or criteria that provide basic criteria for the correct use of words.

The connotative meaning of Leech (1981) is related to real-world experiences associated with the linguistic expressions that people use or hear. Connotative meaning is a device when compared with conceptual meaning. It is also relatively unstable because it varies according to culture, historical period and individual experience. The connotative meaning is uncertain and open-ended. This is because this depends on the knowledge and trust of the speakers and may belong to the reference, real or imaginary characteristics as identified by the speaker. But conceptual meaning consists of a limited number of closed features. Leech definition of connotative meaning is very different from the connotation of Zgusta as a component of lexical meaning, and the use of connotative John Lyon is different from denotation. The so-called Leeches of social and affective meaning are included by Zgusta (1971) under the connotation. Lyon and others call affective or emotive, which means connotation.

\subsection{Affective Meaning}

Affective meaning is related to the speaker's personal feelings or attitudes. In a way that is comparable to social meaning, the affective meaning is only indirectly related to conceptual representation. Leech (2003: 27-28) states that affective meaning is often explicitly conveyed through the conceptual or connotative content of the words used. For example, McDonalds 'motto is "I'm Lovin' It". The word "Lovin 'It" as proof that this sentence describes the feelings of the writer and reader towards the product.

\subsection{Collective Meaning}

Leech (2003: 30) states that the collocative meaning consists of the association of words obtained because of the meaning of words that tend to occur in their environment. For example, the words 'beautiful and handsome'. Beautiful and handsome share similarities in the meaning of "Good looking", but can be distinguished by the range of nouns with which they tend to appear or unite: Beautiful: girls, boys, girls, parks, flowers, colors, villages, etc.

$$
\begin{aligned}
& \text { Handsome } \rightarrow \quad \text { boy, man, car, vessel, overcoat, } \\
& \text { airliner, typewriter, etc. }
\end{aligned}
$$

It could be that the words overlap like a handsome woman and a beautiful woman. Both are acceptable, even though they have different appeal because of the collocative association of the two adjectives.

This present study must mention Leech's quote to clearly define the type of colocative meaning: "The meaning of the collocative consists of the associations that words acquire because of the meaning of words that tend to occur in their environment." (Leech 1981, 17) To clarify his definition, he uses examples of adjectives "beautiful" and "handsome" and words usually found around them.

In terms of the colloidal meaning, quasi-synonyms need to be mentioned, such as "wandering" and "walking", in which Leech explains that "cows may roam, but may not walk" (1981: 17). Moreover, one can only "tremble" with fear and, on the other hand, only "tremble" with excitement. (1981: 17).

\subsection{Associative Meaning}

Associative meaning describes the combination of six modes of language use, which refers to certain mental connections. Such connections are based on the closeness of real-world experience rather than the linguistic context. The next discussion focuses on four types of associative meanings, selected based on different specific communicative properties, e.g. connotative meaning, social meaning, affective meaning, and collocative meaning.

\subsection{Social Meaning}

Languages associated with social languages (1981: 14) Because this is closely related to various social groups that are part of the situation, David Crystal and Derek Davy form a collection of sociostyle variations that correspond to 3 (1969: 66):

a) Dialect (Language of geographical area or social class)

b) Time (e.g. 18th-century language)

c) Province (Legal language, science, advertising, etc.

d) Status (Polite, colloquial, slang, etc.)

e) Modalities (Language memoranda, lectures, talks, etc.)

f) Singularity (Style Dickens, Hemingway, etc.) 
Therefore, words can be announced with conceptual and social meanings that are both very rare, and, to prove that, Leeches add samples while comparing conceptual synonyms with different style meanings. (1981, 14). Depending on the situation, social meaning can include what is called the power of illocution, which can then be interpreted as requests, apologies, challenges, etc., requested by Leech. (1981: 15)

\subsection{Thematic Meaning}

This type of thematic meaning provides an answer to the question: "What is communicated by the way the author shapes and organizes messages?" Which can be considered part of a semantic sentence. (Leeches 1981: 19) There are several examples of these events, such as examples where active and passive sentence construction is confronted, e.g. Mr X donated the first prize. (Active) Vs. The first prize was donated by Mr X. (Passive) (Leech 1981: 19)

However, in essence, Leech states that the thematic meaning is "a matter of choice between alternative grammatical constructions", for example, in the sentence "A man is here to meet you." And "There is a man here to see you". (1981: 19) In addition, emphasis by replacing one element with another or stress and intonation can also be very important when dealing with this type of meaning. (1981: 19-20).

\section{Conclusion}

Some studies believed that the study of meaning in the broader sense would bring about the study of semantic in the next level. Inline of it this study thinks all that is communicated by language'; will not limit their practice by learning logical or conceptual meanings and this is exactly semantic need to put side by side with broaden perspective. It doesn't take great insight to see those semantics in the previous sense, and broader can bring us once again into the emptiness from which Bloomfield as the object of human knowledge or belief. This study believes every scholar can, by carefully distinguishing the types of meanings, show how they all fit in with the total combined effects of linguistic communication can bring about semantic onto more vary perspectives. The basic thought this study proposes is how people can know the right words to use with other words in a sentence into more vary used and context-based. In English, sometimes one word has a synonym with another word, but not all synonym words can be used with other words. It depends on the context of the sentence.

This research has similar thought with Leech that believes in nature. There are seven types of meaning based on Leech's theory, and the first is Conceptual Meaning = Logical, cognitive or connotative content . Second, Connotative Meaning $=$ What is communicated based on what is referenced by language. Third is Social Meaning $=$ What is communicated about the social state of language. The next is Affective Meaning $=$ What the speaker's feelings and attitudes communicate through language. The fifth is Reflected Meaning $=$ What is communicated through association with other Senses from the same world. Then, Collective Meaning = What is communicated through association with words that occur together with other words. The last one is Thematic Meanings = What is communicated in the way in which messages are arranged in order and emphasis.

\section{Acknowledgement}

This research was supported by SMKN 5 Pekanbaru. Therefore, the researchers owe gratitude to their research supervisor and colleague who have given productive criticism in the production of this research study.

\section{References}

Abdelaal, N. M. (2018). Translating connotative meaning in the translation of the Holy Quran: Problems and solutions. AWEJ for Translation \& Literary Studies, Volume2, (1).

Altstiel, T and Grow, J. 2008. Advertising Strategy (Creative Tactics from the Outside/In). Singapore: Seng Lee Press Pte. Ltd.

Bloomfield. 1933:139. Language. New York: Compton Printing LTD. Cann, Ronnie. 1994. Formal Semantics. New York: Cambridge University Press. Chaer, Abdul. 1990. Pengantar Semantik Bahasa Indonesia. Jakarta: Rineka Cipta Djajasudarma, Fatimah. 2009. Semantik 2 Pemahaman Ilmu Makna. Bandung: Refika Aditama 2009.

Crystal, D. 1987. The Cambridge Encyclopedia of Language. Melbourne, Australia: Cambridge University Press.

Crystal, D. 1991. A Dictionary Of Linguistics and Phonetics 3rd Edition. Cambridge, MA: Bsil Blackwell.

Dingxiasong. 1998. The understanding of the slogans/taglines. E-Journal on-line. 23 April 2010.www.dingxiasong@sina.com

Dutamurty. E. N. 2013. Associative Meaning on www.khilafah.com. Surabaya: Surabaya State University.

Harefa, D. K., \& Ginting, I. (2018). Associative meaning of hendihendi in giving afo in nias wedding ceremony. The episteme Journal of linguistics and literature, 4(3). 
Hurford, James., Heasley, Brendan., and Smith, Michael. 2007. Semantics a Course Book. Second ed. New York. Cambridge Press.

Hussein, H. A. H. (2017). Types of Meaning Exploited in Advert's Textuality: A semantic approach. Journal of Al_Anbar University for Language and Literature, (25), 170-185.

Hussein, H. A. H. (2017). Types of Meaning Exploited in Advert's Textuality: A semantic approach. Journal of Al_Anbar University for Language and Literature, (25), 170-185.

Jindal, D.V and Syal, Pushpinder. 2002. An Introduction To Linguistics: Language Grammar and Semantics. New Delhi: Asoke K. Ghosh

Kridalaksana, Harimukti. 2008. Kamus Linguistik: Introduction to Theoretic Linguistics. Jakarta: PT Gramedia.

Leech, G. 1974. Semantics. New York, U.S.A: Penguin.

Leech, G. 1974. Semantik. Translated by Paina Partana. 2003. Yogyakarta: Pustaka Pelajar.

Leech, Geoffrey. 1981. Semantics The Study of Meaning. Second ed. Great Britain:Penguin Books.

Lyons, J. 1997. Semantics Volume I. Great Britain: University Press, Cambridge.

Maisel, T., \& Lexicology, P. S. (2018). The Meaning of Meaning: Leech's Seven Types of Meaning in Comparison to Palmer's and Lyons' Approaches.

Maroon, I. (2018). A Semantic Analysis of Lyrics Expression (Doctoral Dissertation, Universitas Muhammadiyah Surakarta).

Michaud, M. (2017). On Collocative Meaning. Journal of semantics and EFL.

Morley, G, D. 2000. Syntax IN Functional Grammar: An Introduction to Lexicogrammar in systematic Linguistics. New York: Continum.

Noor, M. and Mustafa, R and Muhabat, F and Kazemian, B. 2015. The Language of TV Commercials' Slogans: A Semantic Analysis. Pakistan: University of Gujrat, Punjab. Vol. 1, pp 7-12

Sarefah, L. 2008. The Associative Meaning in The Headlines of The Jakarta Post. Unpublished Thesis. The State Islamic University of Malang.

Umagandhi, R., \& Vinothini, M. (2017). Leech's seven types of meaning in semantics. International Journal of Multidisciplinary Research and Development, 4.
Wangru, C. (2016). Vocabulary Teaching Based on Semantic-Field. Journal of Education and Learning, 5(3), 64-71.

Wheeler, A. 2003. Designing Brand Identitiy: A Complete Guide to Creating, Building and Maniatining Strong Brands. John Wiley and Sons.

Wiryanti, S. 2015. Associative Meaning of Pornography in Printed Media Advertising Products: A Pragmatic Study. Surakarta: Sebelas Maret University of Surakarta. Vol.36: 370 .

Yusuf, N, L. 2010. A Study on The Associative Meanings of The Jakarta Weekender Magazine. Unpublished Thesis. Maulana Malik Ibrahim State Islamic University of Malang 